\title{
APLIKASI BUILDING INFORMASI MODELING (BIM) TEKLA STRUCTURE PADA KONSTRUKSI ATAP DOME GEDUNG OLAHRAGA UTP SURAKARTA
}

\author{
Kukuh Kurniawan DS 1 \\ ${ }^{1}$ Program Studi Teknik Sipil, Fakultas Teknik Universitas Tunas Pembangunan Surakarta \\ E-mail:kukuhkds@utp.ac.id
}

\begin{abstract}
Abstrak
Pekembangan teknologi informasi dibidang konstruksi berkembang semakin pesat. Teknologi virtual building dengan sistem komputasi dikembangkan dengan prinsip Building Information Modeling (BIM), mampu menciptakan modeling secara 3D di bidang konstruksi (arsitektur, struktur dan MEP). Tekla Structures salah satu perangkat lunak berbasis BIM yang mampu membuat dan mengelola data akurat dan rinci. Tekla Structures mempunyai kemampuan dalam modeling, detailing, engineering, drawing, reporting, scheduling. Pembangunan atap dome baja menggunakan sistem truss pada Gedung Olahraga UTP Surakarta dengan bentang 40meter. Memerlukan detail drawing yang baik pada proses fabrikasi, sehingga didapatkan hasil yang presisi pada saat pemasangan. Proses pemasangan dilakukan secara segmented. Gambar fabrikasi atap dome terdiri dari Gambar Arrangement, Section drawing : Kuda-kuda K1 \& K2, Anchor bolt plan, Lateral \& Windbrace, Purlin \& Sagrod, Detail drawing : Rafter $1 \mathrm{~s} / \mathrm{d} 13$, Cutting plan. Dan report bill of materials (BOM) terdiri dari Assembly List, Assembly Part List, Bolt List, Material List dan Part List.
\end{abstract}

Kata kunci: BIM, Tekla, gambar fabrikasi, atap dome baja

\section{PENDAHULUAN}

Perkembangan teknologi informasi yang semakin pesat diberbagai bidang, khususnya pada bidang konstruksi. Memberikan banyak manfaat pada pekerjaan konstruksi yang mempunyai tingkat kesulitan dan komplek dalam proses pengerjaan. Dalam beberapa pekerjaan konstruksi yang berkaitan beberapa disiplin ilmu, misalnya arsitektur, struktur dan mekanikal elekrikal \& plumbing (MEP). Pada tahap pengerjaan konstruksi mengalami kendala crash (bertabrakan/ berbenturan). Maka diperlukan teknologi yang dapat memodelkan secara virtual building. Virtual building yaitu memasukkan seluruh elemen bangunan ke dalam sebuah database lengkap. Dengan teknologi tersebut diharapkan dapat menggambarkan seluruh elemen struktur secara tiga dimensi (3D). Teknologi virtual building dengan sistem komputasi yang dikembangkan didasarkan pada prinsip Building Information Modeling (BIM), mampu menciptakan modeling secara $3 \mathrm{D}$ berbagai bidang konstruksi (arsitektur, struktur dan MEP).
Tekla Structures merupakan salah satu perangkat lunak berbasis BIM yang mampu membuat dan mengelola data secara akurat dan rinci. Tekla Structures mempunyai kemampuan dalam modeling, detailing, engineering, drawing, reporting, scheduling. Tekla Stuctures biasanya digunakan dalam perencanaan bangunan baja, karena umumnya dalam perencanaan bangunan struktur baja memerlukan gambar pelaksanaan yang detail pada sambungan-sambungan. Sehingga pada tahapan fabrikasi diperlukan gambar detail atau shop drawing pada proses marking (penandaan), cutting (pemotongan), drilling (pengeboran), assembling (penyetelan) dan welding (pengelasan).

Pembangunan konstruksi atap dome baja menggunakan sistem truss pada Gedung Olahraga UTP Surakarta dengan bentang 40 meter (gambar 1). Memerlukan detail drawing yang baik pada proses fabrikasi (roll), sehingga didapatkan hasil yang presisi pada saat pemasangan. Dan proses pemasangan dilakukan secara segmented. 

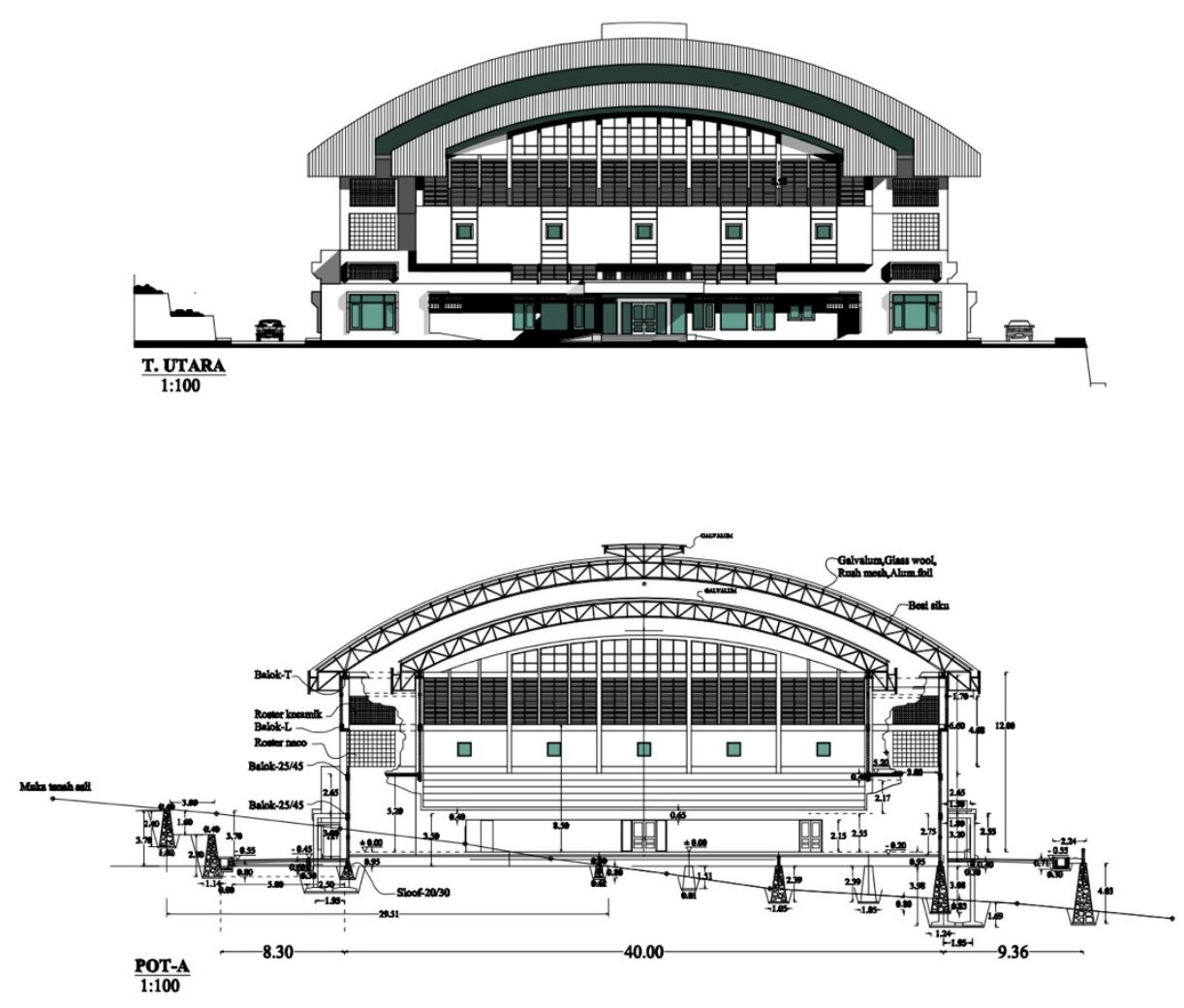

Gambar 1. Gambar Desain Struktur Atap Dome Baja (file CAD)

\section{TINJAUAN PUSTAKA}

\section{Building Information Modeling (BIM)}

Building Information Modeling (BIM) adalah teknologi dan proses revolusioner yang dengan cepat mengubah cara memahami bangunan, desain, konstruksi dan mengoperasikan (Hardin, 2009).

Dari perspektif teknologi, buiding information modeling adalah simulasi proyek yang terdiri dari model 3D komponen proyek dengan menghubungkan semua informasi yang diperlukan pada perencanaan, desain, konstruksi dan pengoprasian (Kymmell, 2008), Gambar 2.

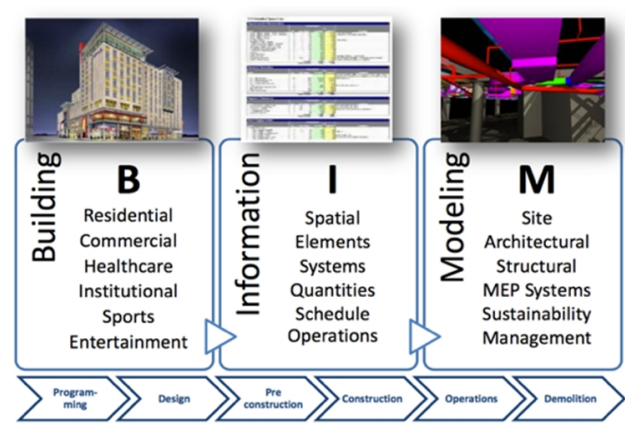

Gambar 2. Gambaran Konsep BIM

\section{Tekla Structures}

Tekla Structures adalah perangkat lunak building information modeling (BIM) 3D yang digunakan dalam industri bangunan dan konstruksi untuk pendetailan baja dan beton, pracetak dan casting in-situ. Perangkat lunak ini memungkinkan pengguna untuk membuat dan mengelola model struktural 3D dalam beton atau baja, dan memandu mereka melalui proses dari konsep hingga pembuatan. Proses pembuatan gambar kerja atau shop drawing dilakukan secara otomatis.

Tekla Structures BIM merupakan software BIM berbasis ensiklopedi proyek yang memungkinkan untuk membuat dan mengelola data secara akurat dan rinci, serta dapat membuat model struktur 3D tanpa melupakan material dan struktur yang kompleks (Saputri, 2012).

Software Tekla merupakan revolusi baru dalam bidang rekayasa struktur yang memiliki beberapa keunggulan dibanding program aplikasi lainnya. Keunggulan Software Tekla antara lain yaitu terintegrasinya kegiatan pemodelan, analisis dan desain struktur dengan detailing yang lebih detail, bill quantity, sequence pekerjaan sampai dengan kegiatan schedulling bahkan dapat digabungkan dengan 
software lainnya seperti perencanaan produksi, sumber daya, sistem otomatisasi mesin, dsb (Gambar 3). Sehingga kegiatan AEC (architect, engineering, construction) terintegrasi dalam satu pemodelan yang dapat diakses secara real time (Azhar, 2012)

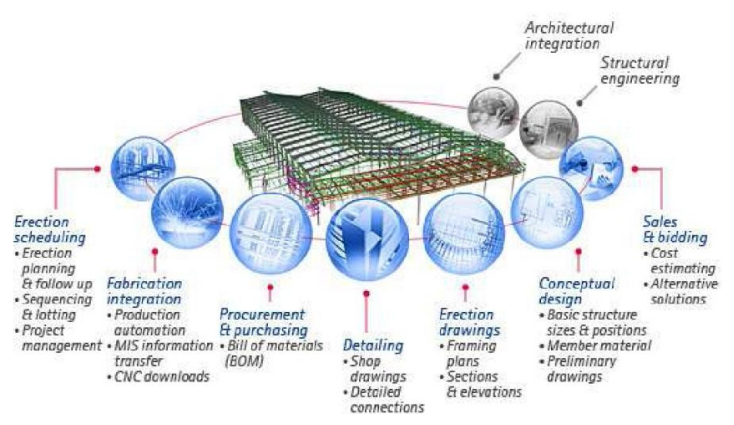

Gambar 3. Integrasi kemampuan Tekla

\section{Manfaat Pendetailan Struktur Baja dengan Tekla Structures}

Tekla Structures digunakan untuk menghasilkan gambar kerja (shop drawing) dan gambar pemasangan (erection) dan melaporkan secara otomatis dengan akurasi hampir 100\% (Firoz \& Rao, 2012).

Hasil dari modeling struktur baja dengan Tekla Structures diantaranya adalah :

1. General Arrangement Drawing (plan, section, erection)

2. Bill of Materials (BOM)

3. Model 3D Tekla

4. Rencana pemasangan (erection plan)

5. Rencana baut angkur (anchor bolt setting)

6. Gambar kerja atau shop drawing (steel fabrication drawing)

7. Detail sambungan (detail connection)

Pendetailan, Fabrikasi dan Pemasangan Stuktur Baja

\section{Pendetailan Struktur Baja}

Membuat model yang akurat dan detail merupakan keuntungan penggunaan Tekla Structures. Semua jenis struktur baja dan detail dapat dibuat modelnya dengan mudah dan fitur clash check (cek ketidakserasian) secara otomatis memastikan setiap konflik yang beresiko pada pembiayaan, akan terdeteksi dalam modeling dan tidak pada tahap produksi atau konstruksi.
Gambar, laporan dan data CNC dapat dibuat secara otomatis dari model 3D kapan saja diperlukan. Gambar terintegrasi sepenuhnya dengan model, memungkinkan manajemen perubahan yang efektif namun mudah.

Mengerjakan pendetailan dengan struktur 3D virtual akan terkoneksi secara cerdas dan akurat dengan situasi yang bervariasi dan berubah-ubah. Tekla structures mempunyai fitur pendetailan sambungan baja dan welded bolt.

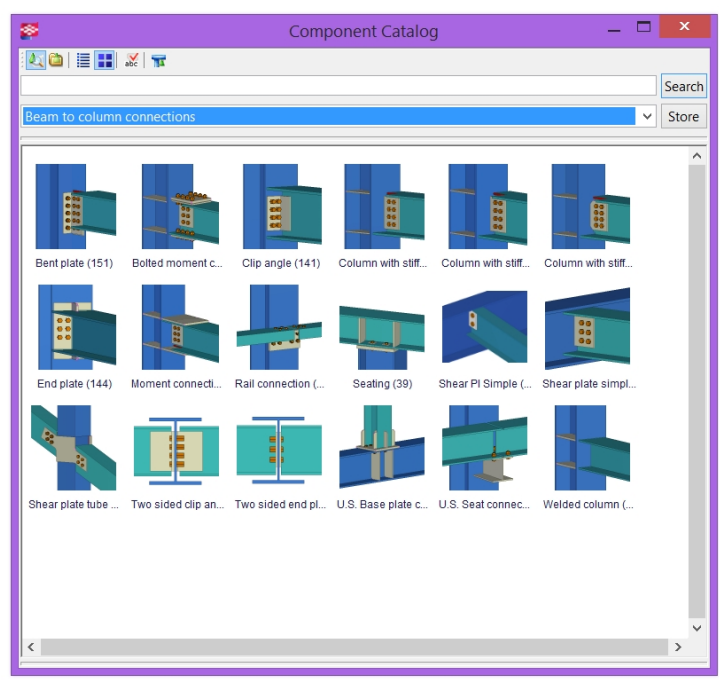

Gambar 4. Fitur Detail Sambungan BalokKolom pada Tekla Structures

\section{Fabrikasi Struktur Baja}

Pada tahap fabrikasi diperlukan dokumen gambar fabrikasi atau shop drawing. Gambar fabrikasi adalah gambar dari suatu bentuk barang atau alat-alat produksi maupun konstruksi yang akan dibuat oleh seorang fitter.

Aplikasi Building Informasi Modeling (BIM) Tekla Structure Pada Konstruksi Atap Dome Gedung Olahraga Utp Surakarta

Secara umum gambar fabrikasi terdiri dari :

- General drawing atau gamber arrangement, gambar fabrikasi yang menunjukkan bentuk secara menyeluruh dari suatu produk yang akan dibuat.

- Section drawing, gambar yang menunjukkan salah satu atau beberapa bagian dari item/ produk yang akan dibuat berdasarkan arrangement drawing.

- Detail drawing, gambar yang 
menunjukkan iitem tertentu dengan maksud untuk memperjelas ukuran, jarak lubang, tipe pengelasan dan lain-lain. Detail drawing ditandai dengan lingkaran dan huruf $A, B, C$ dan seterusnya.
- Cutting plan, gambar yang menunjukkan bentuk potongan dari masing-masing item beserta jenis material,ukuran maupun tebal plat.

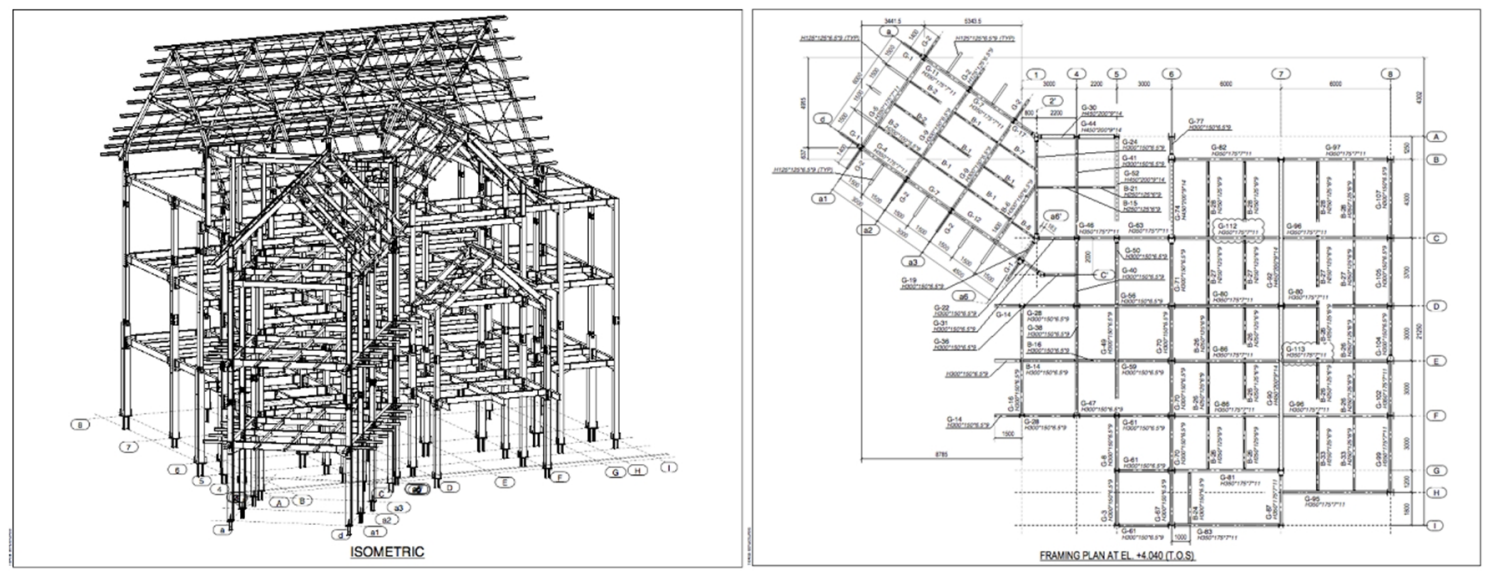

Gambar 5. Gambar Arrangement \& Section Drawing

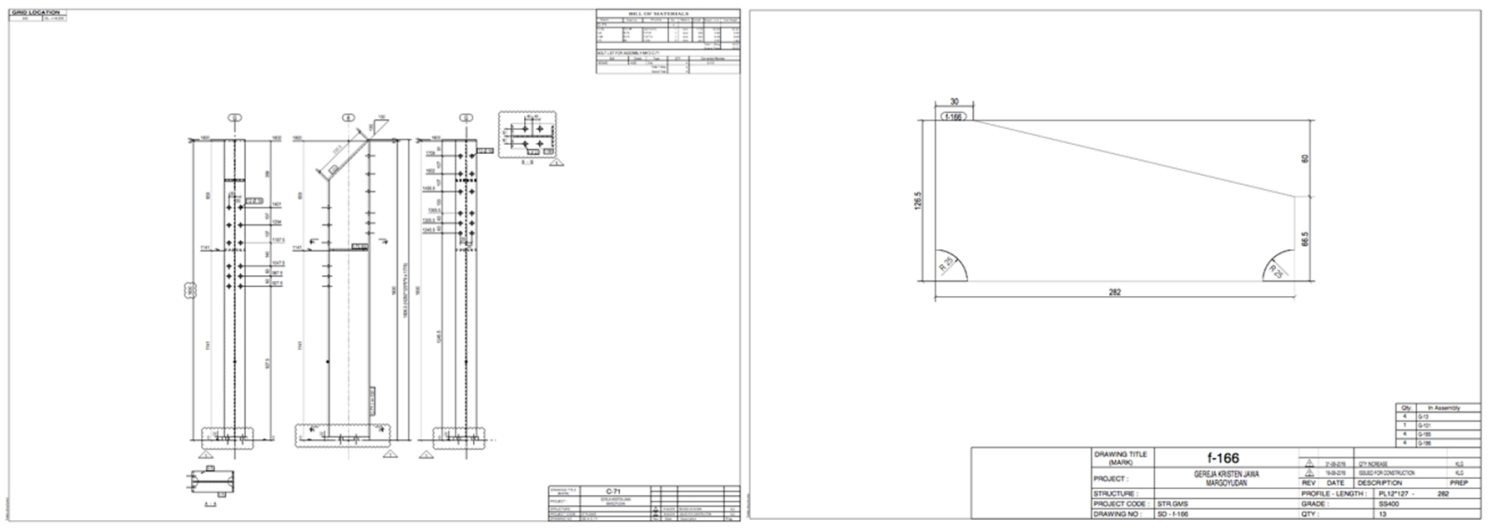

Gambar 6. Detail drawing dan Cutting Plan

\section{Pemasangan (Erection)}

Pada tahap pemasangan (Gambar 7), dimungkinkan untuk pelacakan kemajuan progress fabrikasi secara jelas dan efektif pada bagian yang akan dipasang. Fabrikasi dengan gambar shop drawing dapat dikontrol urutan prioritas part atau bagian yang dipasang. Sehingga urutan dalam pemasangan dapat direncanakan secara jelas, termasuk merencana pengiriman dan metode kerja berkaitan dengan alat bantu.

\section{Bill of Material (BOM)}

Dari pemodelan yang menghasilkan gambar fabrikasi atau shop drawing, juga menghasilkan laporan berupa kebutuhan material aktual. Laporan tersebut berupa tabel material baja, pelat, baut, cat, dan lain-lain yang biasa disebut bill of material (BOM). Tabel BOM biasanya terdiri dari jumlah, panjang, berat per material, luasan permukaan dan lain-lain.

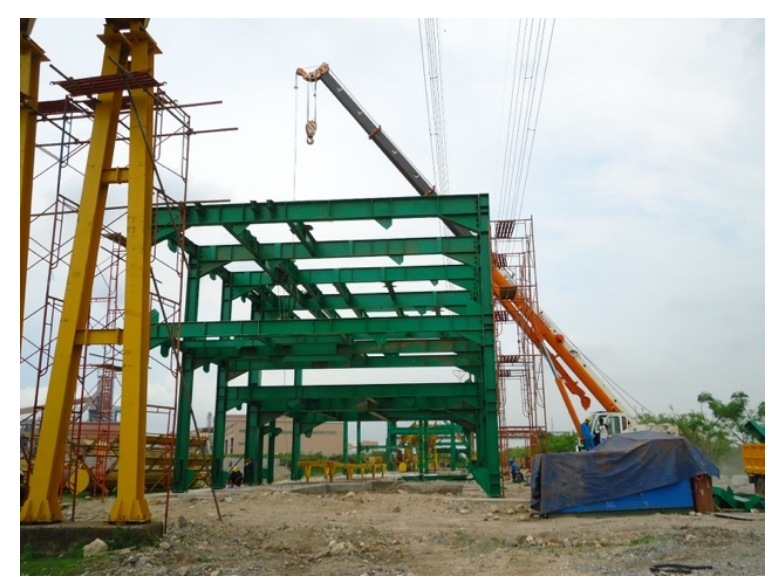

Gambar 7. Pemasangan konstruksi baja 


\section{METODOLOGI PENELITIAN}

Metode yang digunakan adalah dengan memodelkan atap baja dome sistem truss dengan perangkat lunak Tekla Structure. Output dari desain adalah gambar general arrangement, shop drawing dan material \& bolt list.

\section{HASIL DAN PEMBAHASAN}

\section{Hasil}

Model atap baja dome sistem truss dari program Tekla Structures yang sudah di export ke Tekla BIMsight terlihat pada Gambar 8.

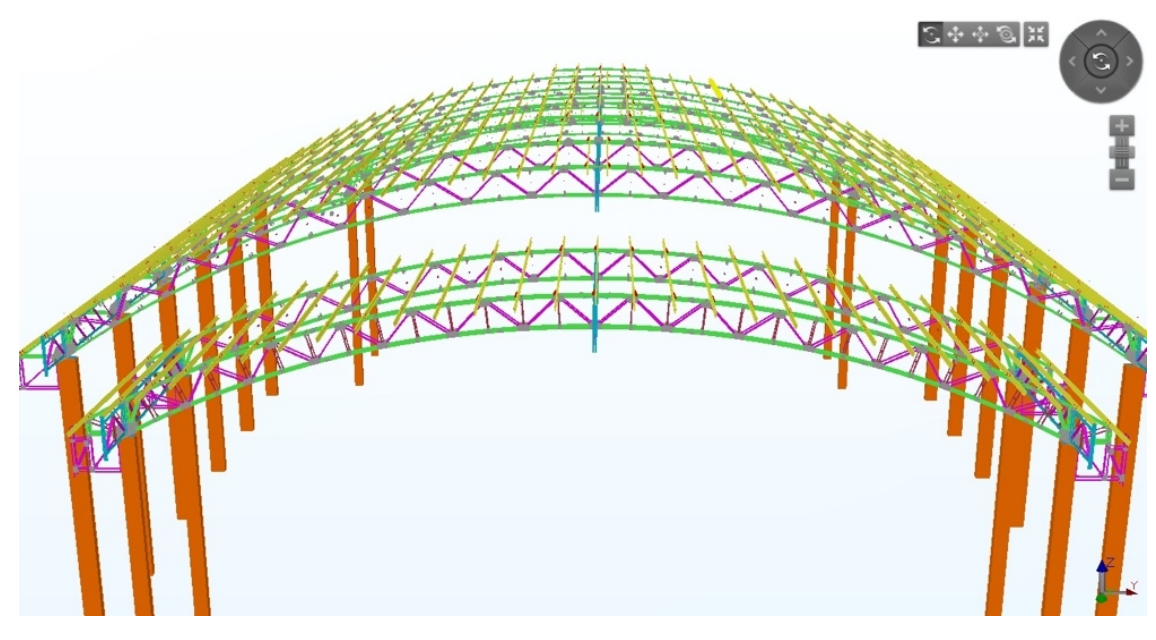

Gambar 8. Hasil Pemodelan Tekla Structure di Bimsight

- Gambar Fabrikasi (Shop drawing)

Gambar fabrikasi untuk kebutuhan fabrikasi terdiri dari gambar 3D, gambar arangement, section drawing dan part drawing. List gambar fabrikasi sebagai berikut:

1) Gambar Arrangement
2) Section drawing: Kuda-kuda $K 1 \& K 2$, Anchor bolt plan, Lateral \& Windbrace, Purlin \& Sagrod.

3) Detail drawing : Rafter $1 \mathrm{~s} / \mathrm{d} 13$

4) Cutting plan

Berikut gambar fabrikasai untuk section drawing kuda-kuda tipe $\mathrm{K} 1$ yang terdiri dari detail drawing RF 2, RF3, RF6, RF7, RF8 dan RF10.

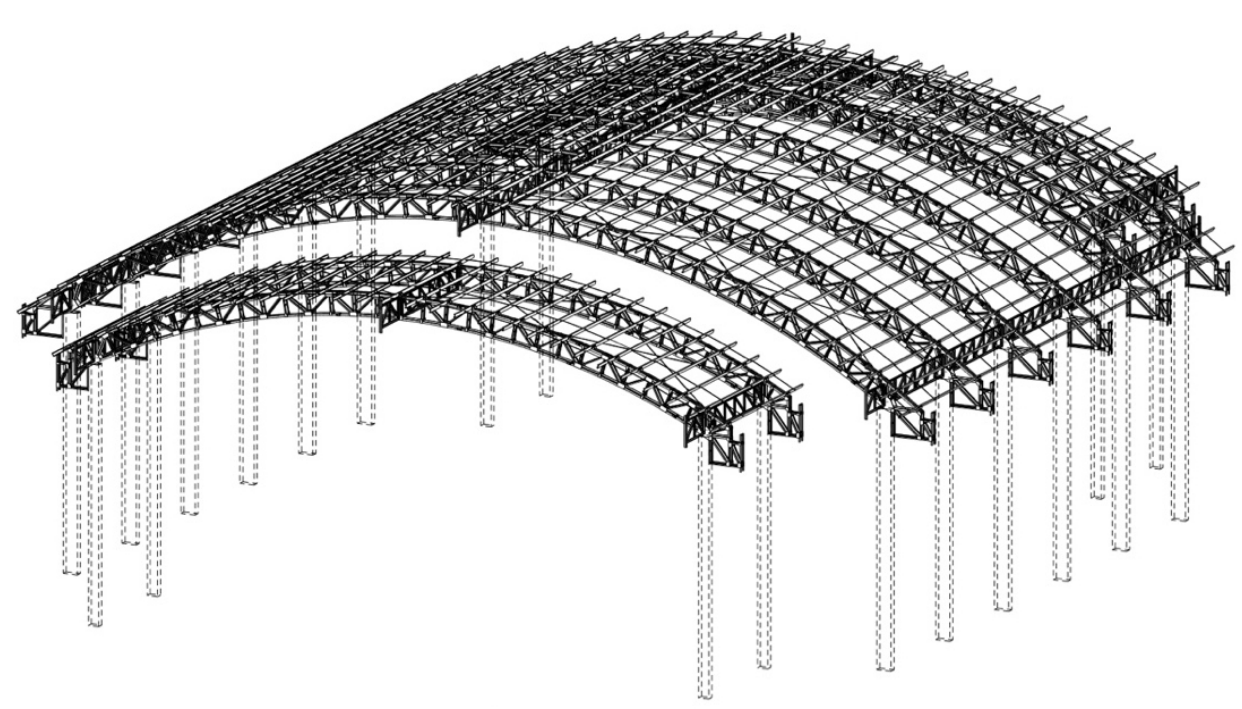

ISOMETRIC

Gambar 9. Gambar Arrangement Atap Dome 


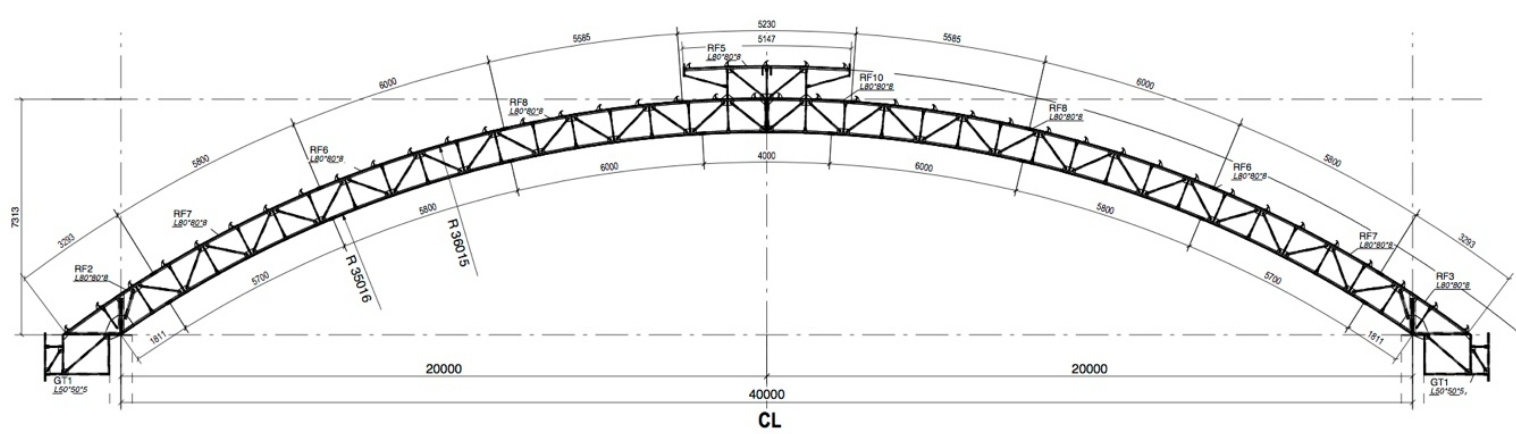

$\underset{\text { GRID D \& GRID G }}{\text { KUDA-KUDA K1 }}$

Gambar 10. Section Drawing Atap Dome Tipe K1

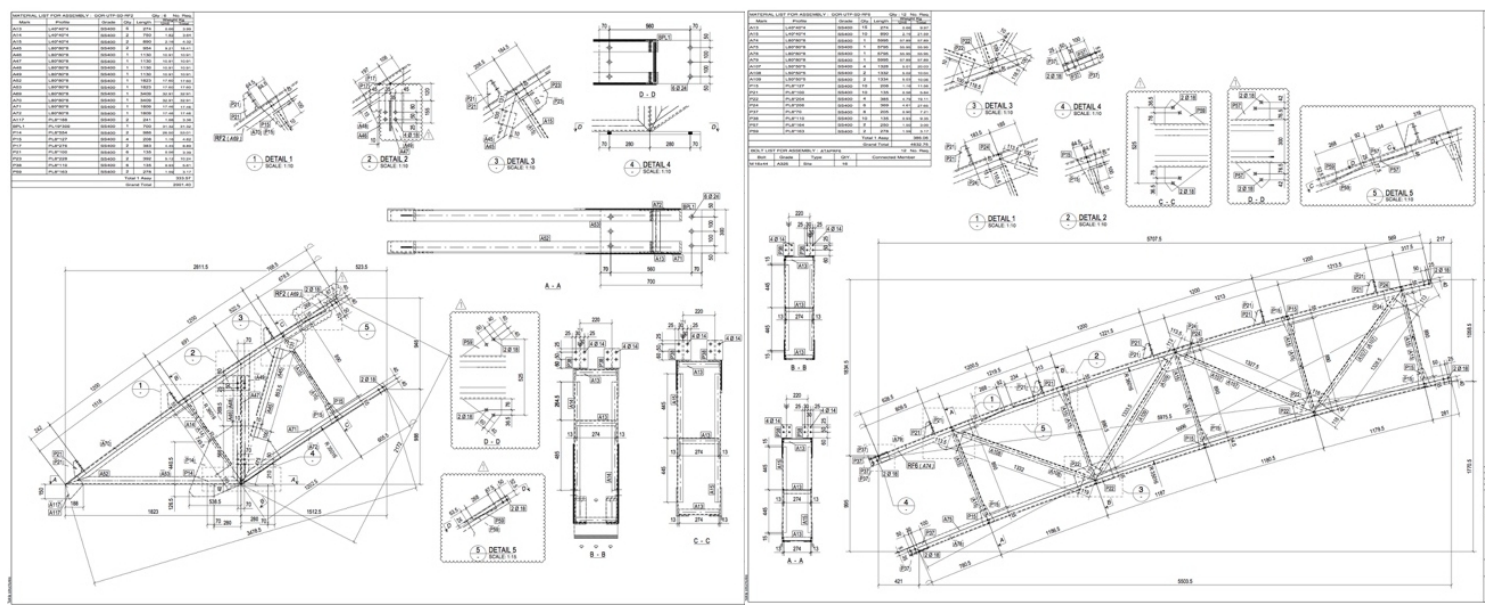

Gambar 11. Detail Drawing Rafter

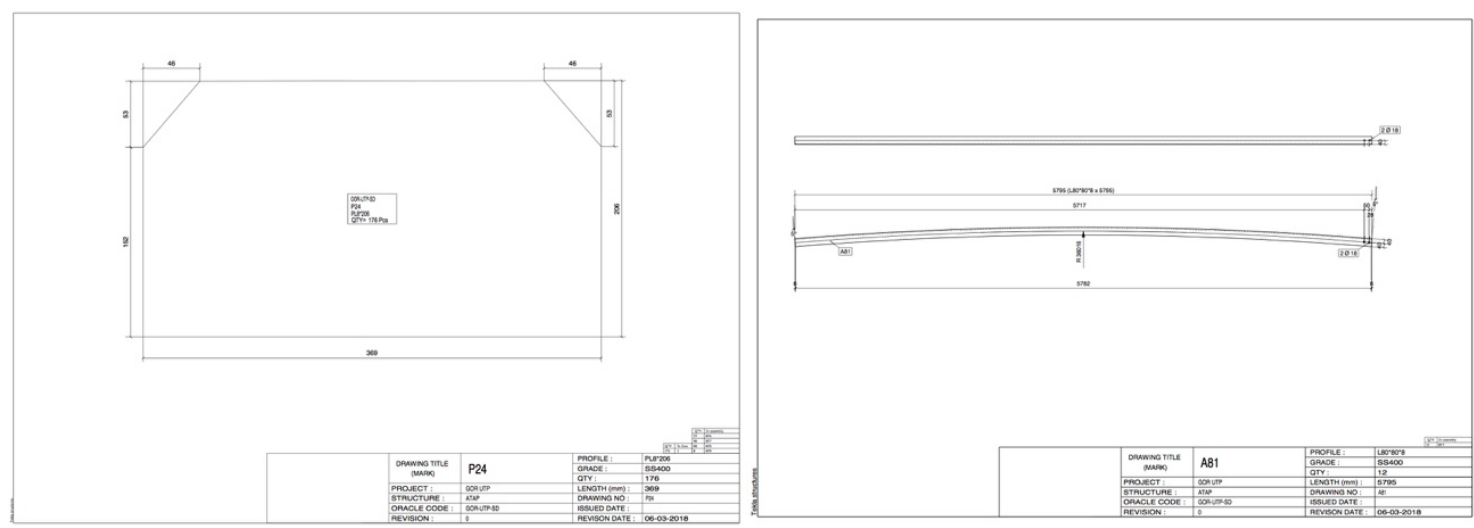

Gambar 12. Cutting Plan

- $\quad$ Bill of Material (BOM)

Hasil laporan kebutuhan material dari output model atap baja dome terdiri dari assembly list, assembly part list, bolt list, material list dan part list.
Setiap laporan BOM tersusun secara tabulasi yang menginformasikan, profile material, panjang, luas, berat, jumlah dan lainlain. Hasil laporan BOM seperti pada tabel dibawah ini. 


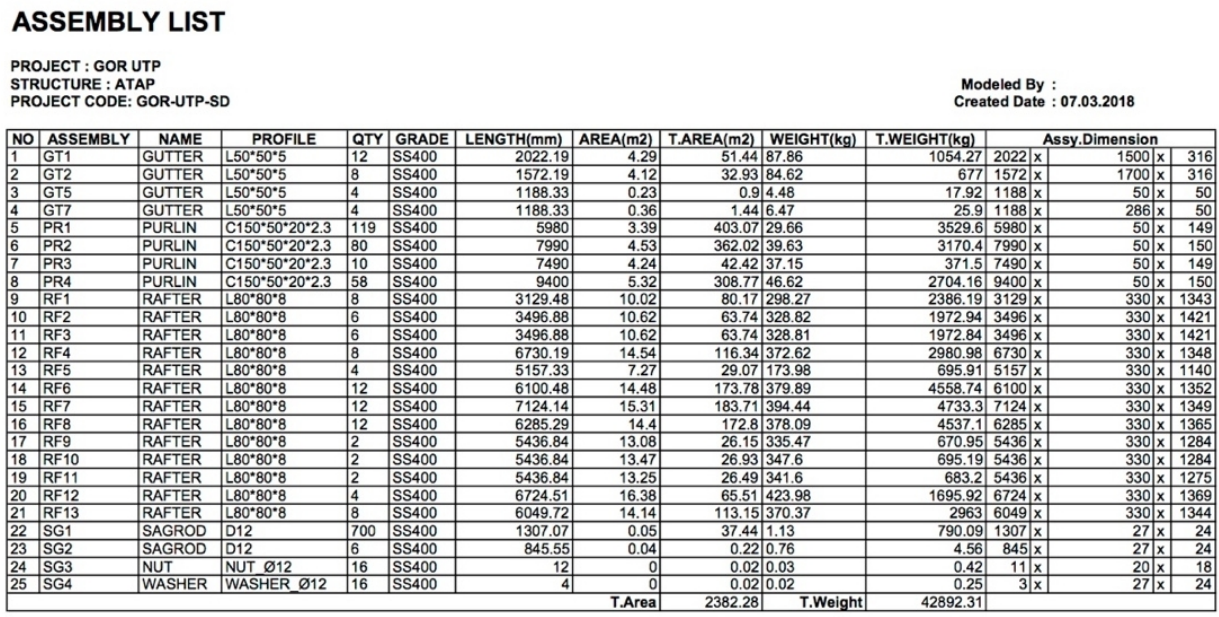

Tabel 1. Assembly List

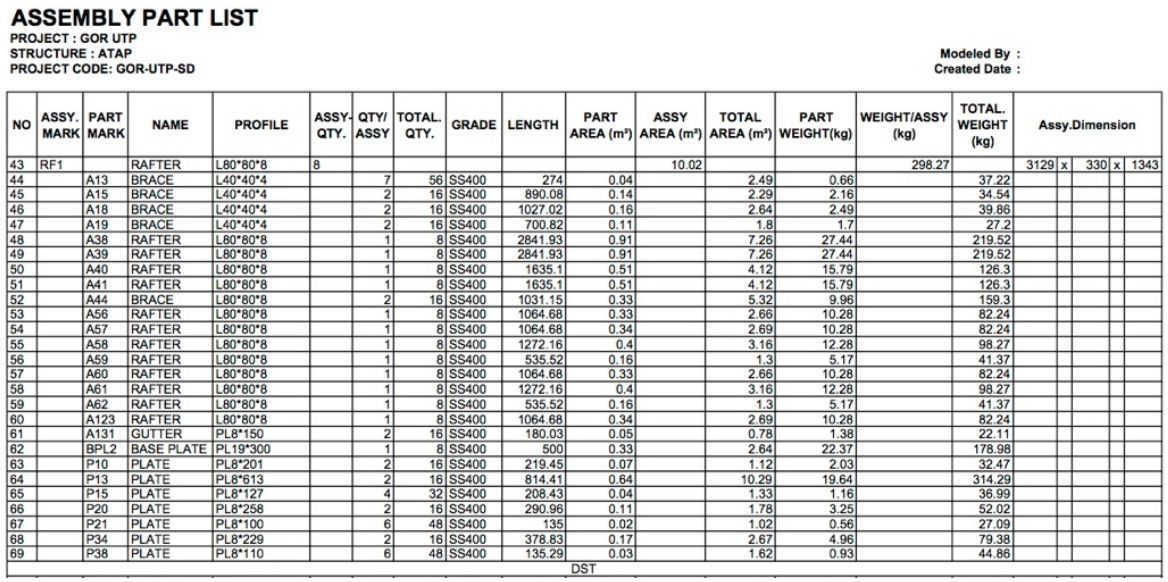

Tabel 2. Assembly Part List

BOLT LIST

PROJECT : GOR UTP

STRUCTURE : ATAP Modeled By

PROJECT CODE: GOR-UTP-SD Created Date : 07.03.2018

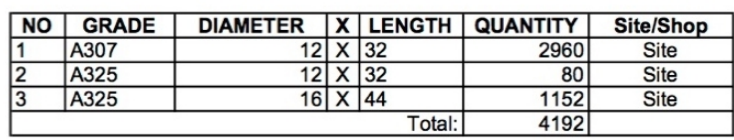

Tabel 3. Bolt List

MATERIAL LIST BY SIZE

\begin{tabular}{|c|c|c|c|c|c|c|}
\hline \multicolumn{6}{|c|}{$\begin{array}{l}\text { PROJECT : GOR UTP } \\
\text { STRUCTURE : ATAP } \\
\text { PROJECT CODE: GOR-UTP-SD }\end{array}$} & \multirow{2}{*}{$\begin{array}{c}\begin{array}{c}\text { Modeled By } \\
\text { Created Date }\end{array} \\
\text { AREA(m2) }\end{array}$} \\
\hline SIZE & PART MARK & NAME & GRADE & QTY & LENGTH & \\
\hline C150*50*20*2.3 & PR4 & PURLIN & SS400 & 58 & 9400 & 5.32 \\
\hline C150*50*20*2.3 & PR2 & PURLIN & SS400 & 40 & 7990 & 4.53 \\
\hline C150*50*20*2.3 & PR2 & PURLIN & SS400 & 39 & 7990 & 4.53 \\
\hline C150*50*20*2.3 & PR2 & PURLIN & SS400 & 1 & 7990 & 4.53 \\
\hline C $150 * 50 * 20 * 2.3$ & PR3 & PURLIN & SS400 & 10 & 7490 & 4.24 \\
\hline \multirow[t]{2}{*}{$\mathrm{C} 150^{*} 50^{*} 20^{*} 2.3$} & PR1 & PURLIN & SS400 & 119 & 5980 & 3.39 \\
\hline & & & & TOTAL & 1970919.97 & 1116.28 \\
\hline $260 * 60 * 6$ & A32 & BRACE & SS400 & 24 & 890.56 & 0.22 \\
\hline L60*60*6 & A31 & BRACE & SS400 & 8 & 870.69 & 0.21 \\
\hline \multirow[t]{2}{*}{$660^{*} 60^{*} 6$} & A31 & BRACE & SS400 & 8 & 870.69 & 0.21 \\
\hline & & & & TOTAL & 35304.47 & 8.53 \\
\hline
\end{tabular}

Tabel 4. Bolt List \& Material List 


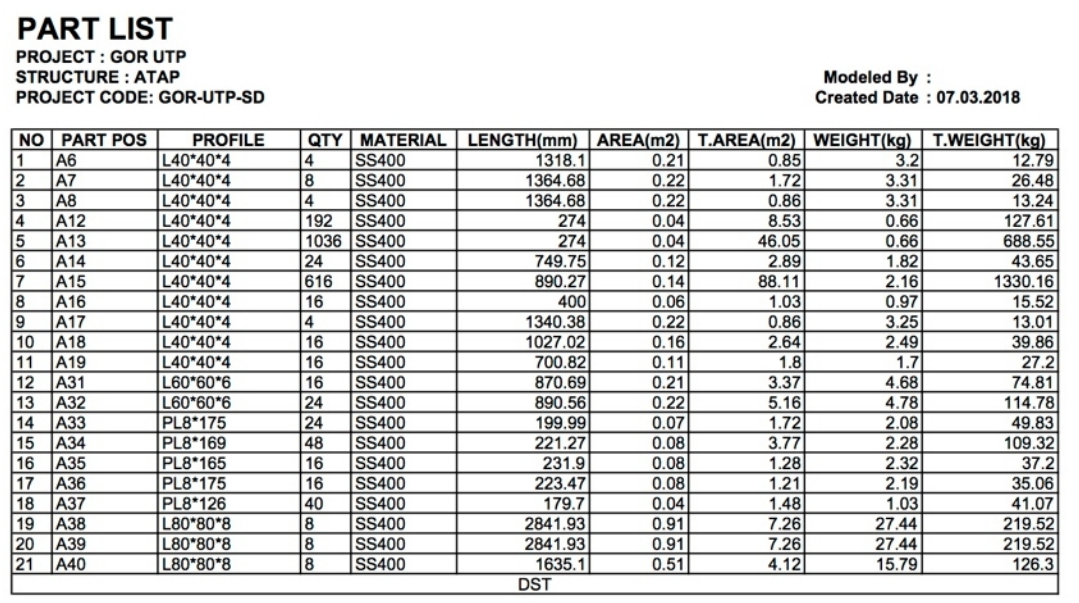

Tabel 5. Part List

\section{Pembahasan}

- Gambar Fabrikasi (Shop drawing)

Gambar fabrikasi yang dihasilkan dari pemodelan dengan software berbasis building information modeling atau BIM, memiliki tingkat akurasi yang sangat baik. Setiap bagian-bagian struktur atap termarking dengan detail. Detail material yang terpasang sekecil apapung dapat terdetailkan dengan baik.

Posisi lubang dan orentasi pelengkungan (roll) material untuk memperoleh bentuk dome setiap segment dijelaskan dengan detail. Sambungan antar material menggunakan baut, tampak jelas jumlah, ukuran dan jarak antar lubang.

Pada gambar part list, semua material yang diperlukan tergambar jelas perbagian material. Serta terdapat informasi terkait jumlah dan berat material tersebut. Setiap part-part material memiliki informasi letak detail drawingnya.

Section drawing selain sebagai gambar fabrikasi, juga berfungsi erection drawing (gambar pemasangan). Karena setiap marking detail drawing terlihat jelas pada section drawing tersebut.

- Bill of Material (BOM)

BOM hasil output laporan pemodelan, mempunyai peranan penting dari tahapan fabrikasi berkaitan dengan pembelian material dan jenisnya. Setiap jenis profil yang dipakai tersusun dalam tabel dengan informasi berat material dan panjang. Terdapat luasan pada list material, informasi ini dapat digunakan sebagai dasar dalam pembelian bahan cat.

Data bolt list, tersusun dalam tabulasi dengan informasi dimensi dan panjang baut. Panjang baut diinformasikan secara detail, dan terhubung dengan erection drawing. Karena kebutuhan panjang dan dimensi yang berbeda pada setiap joint, bolt list ini dapat membantu dengan baik. adalah :

Kebutuhan total material atap baja dome

- Berat total material

: 42,892.31 kg

- Kebutuhan baut

$4,192.00 \mathrm{pcs}$

- Luas permukaan cat

$2,382.28 \mathrm{~m}^{2}$

\section{PENUTUP}

\section{Kesimpulan}

- Pekerjaan konstruksi baja yang memiliki kompleksitas dan ketelitian dalam pengerjaan diperlukan gambar detail yang baik untuk fabrikasi.

- Gambar fabrikasi menggunakan Tekla Structure memudahkan dalam proses fabrikasi atap baja dome yang memerlukan ketelitian.

- Perencanaan fabrikasi terhadap alur pemasangan saat konstruksi dilakukan sesuai rencana metode pemasangan dengan bantuan gambar fabrikasi.

- Laporan bill of material (BOM) dari pemodelan atap baja dome memudahkan 
dalam mengkontrol kebutuhan material fabrikasi dan pemasangan.

\section{Saran}

- Pembuatan gambar fabrikasi untuk pekerjaan konstruksi baja perlu dilakukan dengan bantuan perangkat lunak berbasis building information modeling (BIM).

- Tekla Structures memberikan hasil yang maksimal dalam pembuatan gambar fabrikasi.

- Gambar berbasis berbasis BIM tidak hanya dapat dilakukan pada konstruksi baja, tetapi konstruksi beton bertulang perlu dilakukan pemodelan secara virtual building.

\section{DAFTAR PUSTAKA}

Azhar, S et al. (2012) 'Building information modeling (BIM): now and beyond', Australasian Journal of Construction Economics and Building, 12 (4) $15-28$

Hardin, B. (2009) BIM and Construction Management, Indianapolis: Wiley Publishing, IN

Firoz, S., \& Rao, S. (2012). Modelling Concept of Sustainable Steel Building by Tekla Software. International Journal of Engineering Research and Development, 1(5), 18-24.

Kymmell, W. (2008) Building Information Modeling: Planning and Managing Projects with 4D CAD and Simulations, USA:McGraw Hill Construction

Saputri, F. (2012). Penerapan Building Information Modeling (BIM) pada Pembangunan Struktur Gedung Perpustakaan IPB Menggunakan Software Tekla Structures 17. Institut Pertanian Bogor 